\title{
Increased grazing intensity in pastures reduces the abundance and richness of ground spiders in an integrated crop-livestock system
}

\author{
Joice Aline Freiberg ${ }^{1}$ - Cristian de Sales Dambros ${ }^{2} \cdot$ Everton Nei Lopes Rodrigues $^{3} \cdot$ Renato Augusto Teixeira $^{4}$. \\ Ângela Denise Hubert Neufeld Vieira ${ }^{1}$. Hazael Soranzo de Almeida ${ }^{1}$. Paulo César de Faccio Carvalho ${ }^{5}$. \\ Rodrigo Josemar Seminoti Jacques ${ }^{1}$ (i)
}

Accepted: 21 November 2019 / Published online: 17 December 2019

(C) INRA and Springer-Verlag France SAS, part of Springer Nature 2019

\begin{abstract}
Ground spiders can reflect the impacts of land-use intensification. In an integrated annual crop-livestock system, the grazing intensification can negatively influence the abundance and richness of ground spiders. We evaluated the difference in abundance, family and species richness, and species composition of ground spiders in the soybean and pasture environments, and the effect of grazing intensity on the spider community under a soybean-pasture rotation. We hypothesized that pastures would have higher spider species richness and a distinct species composition and that the increase in grazing intensity would reduce spider abundance and species richness. We conducted an experiment in an integrated annual croplivestock system under a soybean-pasture rotation in southern Brazil that was managed for 14 years by alternating Glycine max for summer grain production and Avena strigosa + Lolium multiflorum for beef cattle grazing during the winter. We sampled four times over 2 years: twice after the grazing cycles and twice after the soybean harvests. Grazing intensification was measured as grazing heights of $10,20,30$, and $40 \mathrm{~cm}$. Pitfall traps were installed to capture ground spiders. A total of 2589 spiders were collected and classified into 23 families and 43 species. The abundance of spiders was seven times higher, and species richness was 35\% higher in the postgrazing compared with the postsoybean environment. Linear mixed effects models showed that spider abundance and richness were strongly influenced by grazing height, particularly postgrazing, but the influence of grazing height on male spider abundance could still be detected in the postsoybean environment. We have shown for the first time that the management of grazing height affects the abundance and richness of spiders in an integrated annual crop-livestock system. To introduce a grazing cycle to a completely crop-centric production system and regulating grazing intensity can help maintain a more diverse spider community.
\end{abstract}

Keywords Araneae $\cdot$ Bioindicator $\cdot$ Soil fauna $\cdot$ Soybean $\cdot$ Pasture $\cdot$ Sustainable intensification

Rodrigo Josemar Seminoti Jacques rodrigo@ufsm.br

1 Department of Soils, Universidade Federal de Santa Maria, Santa Maria, RS, Brazil

2 Department of Ecology and Evolution, Universidade Federal de Santa Maria, Santa Maria, RS, Brazil

3 Arachnid Diversity and Systematics Laboratory, Universidade do Vale do Rio dos Sinos, São Leopoldo, RS, Brazil

4 School of Biosciences, Pontifícia Universidade Católica do Rio Grande do Sul, Porto Alegre, Rio Grande do Sul, Brazil

5 Department of Forage Plants and Agrometeorology, Universidade Federal do Rio Grande do Sul, Porto Alegre, RS, Brazil

\section{Contents}

1. Introduction

2. Materials and methods

2.1. Experimental site

2.2. Experimental design

2.3. Ground spider sampling

2.4 Data analysis

3. Results and discussion

3.1. Composition of the ground spider community associated with the integrated crop-livestock system

3.2. Effect of grazing height on the composition of the ground spider community

4. Conclusions

Acknowledgments

References 


\section{Introduction}

Land-use intensification is one option to meet the growing demand for food production without converting native ecosystems to agricultural areas, providing that the intensification avoids soil and environmental degradation through sustainability. Thus, it is necessary to combine agricultural practices with the conservation of biodiversity and ecological function in agricultural landscapes (Rockström et al. 2017). Integrated crop-livestock systems (ICLS) are one alternative for sustainable intensification as they synergistically exploit agricultural and livestock resources in combination with conservationfocused land use and management practices. Combining agricultural crops and pastures (Fig. 1) allows these components to be developed collaboratively and enables more efficient use of agricultural inputs, land and natural resources (Herrero et al. 2010; Kunrath et al. 2015).

In the Brazilian subtropics, the majority of agricultural areas are used for either soybean or corn production in the summer, and in the winter, they remain fallow or are planted with cover crops (i.e., black oats and ryegrass). These large areas could make the production system more economically stable by including pasture with the agricultural crops in an integrated crop-livestock system. With regard to the social and economic effects, including a pasture rotation in an integrated system allows greater efficiency in the operation of property machinery and human resources, a higher income per unit area through the diversification by livestock production and a reduction in agricultural risks and production costs (Moraes et al. 2014). However, the effects of the animal component on the environment are a substantial challenge in implementing this production model. Sustainable intensification, if not managed properly in an integrated crop-livestock

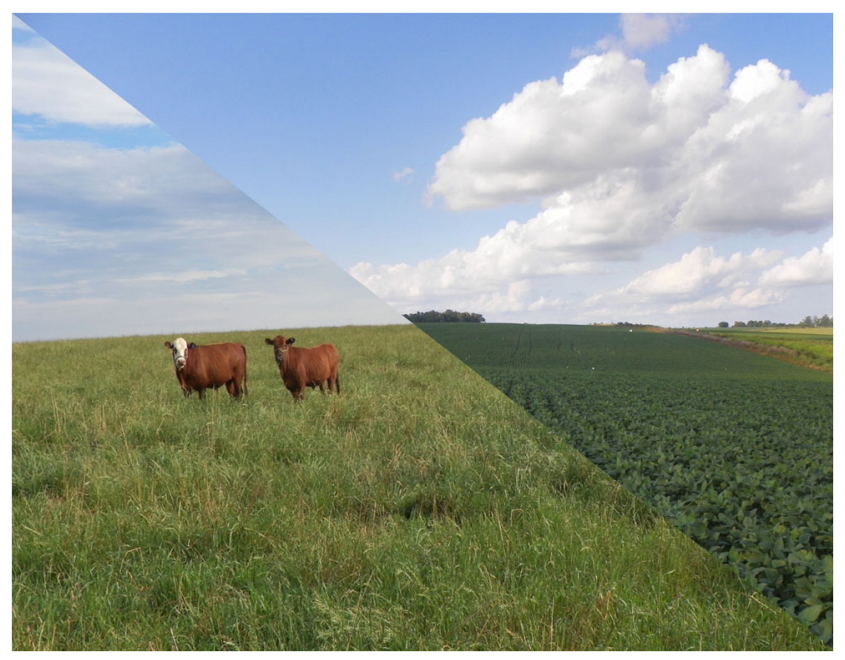

Fig. 1 An overview of the integrated crop-livestock system conducted over 14 years with pasture-soybean succession. Livestock may represent a different income opportunity to farmers who use Avena strigosa and Lolium multiflorum as cover crops system, can lead to decreased soil quality, which is important for grain productivity. Therefore, it is important to establish the animal density that can be used in these systems without compromising the soil and environmental quality.

In particular, intensive grazing harms soil invertebrates, which provide important ecosystem services such as regulation of nutrient availability, carbon sequestration (Bender et al. 2016), pest and disease control (Marín et al. 2016), and biopore formation. The loss of soil invertebrates occurs because overgrazing reduces soil cover, leads to soil compaction, changes soil temperature and humidity regimes, reduces water infiltration, and increases erosion (Eldridge et al. 2017). However, these effects may not be immediate, and the impacts of overgrazing are more easily detected in certain soil groups that respond rapidly to management practices and are highly sensitive to environmental disturbances. Ground spiders can reflect changes in land use and agricultural practices (PrietoBenítez and Méndez 2011) as well as changes in the composition, abundance, and richness of other groups of soil organisms (Dennis et al. 2015). Spiders play an important role in natural biological control (Pekár et al. 2015), and they are sensitive to tillage (Haddad et al. 2011), seeding, harvesting, pesticide application (Rodrigues et al. 2013), grazing practices (Bucher et al. 2016), and plant cover removal (Bell et al. 2001) as well as to changes near the cropping areas.

Among other factors, vegetation has been reported to be a major influence on spider communities. The composition (plant species richness) and structure of vegetation (height of the plants) can reflect the diversity of potential invertebrate prey and habitat for spiders (Gallé et al. 2011). Therefore, low stocking densities of cattle in pasture environments offer more favorable conditions for the presence of spiders. Under low grazing intensity, the higher density, greater height and diversity, and more complicated architecture of plants provide a complex vegetation structure that benefits weaver spiders (Bell et al. 2001) by providing diverse materials and spaces in the litter for the construction of webs, and thus increases spider abundance and diversity (Dennis et al. 2015; Bucher et al. 2016). In an integrated crop-livestock system, the intensification of grazing can alter microhabitats and increase the fragmentation and dispersion of the litter, which reduces the diversity of araneofauna and selects for species associated with uncovered soil. In addition, agricultural regimes can alter spider populations through the availability of shelter and food.

We investigated how the difference between the soybean and pasture environments and variation in grazing intensity impacts the composition of spider communities in an integrated crop-livestock system. Specifically, the aims of the current study were to evaluate (1) the difference in abundance, family and species richness, and species composition of ground spiders in the soybean and pasture environments and (2) the effect of grazing intensity on the spider community under a soybean-pasture rotation. We hypothesized that pastures 
would have higher spider species richness and a distinct species composition and that the increase in grazing intensity would reduce spider abundance and species richness.

\section{Materials and methods}

\subsection{Experimental site}

This study was conducted in an integrated crop-livestock system located at Espinilho Farm in the São Miguel das Missões district, Rio Grande do Sul State (RS), Brazil (28 $56^{\prime} 14.00^{\prime \prime} \mathrm{S}$, $54^{\circ} 20^{\prime} 50.61^{\prime \prime} \mathrm{W}, 417 \mathrm{~m}$ ) (Fig. 2a). This area is in the Cfa (humid subtropical) climatic zone according to the KoppenGeiger classification system. The topography is slightly undulating, and the soil is classified as Rhodic Hapludox (Oxisol). The area consisted of natural pastures until 1993, when it was converted to a cultivated no-tillage soybean (Glycine max L.) cropping area for grain production alternating with black oat (Avena strigosa Schreb.) for seed production. In 2001, an ICLS was established under a soybean-pasture rotation. During the summer (November through April), soybean is cultivated for grain production; after the soybean harvest, the pasture is established by the sowing of black oat and the natural reseeding of Italian ryegrass (Lolium multiflorum Lam.) for continuous beef cattle grazing (May through October) (Kunrath et al. 2014).

\subsection{Experimental design}

To test whether the land use environment (soybean or pasture) and grazing intensity have an effect on ground spiders, we conducted a field experiment where we controlled grazing intensity by regulating the number of steers. The total experimental area comprised approximately 23 ha divided into 14 paddocks. Each paddock contained one of five treatments: four grazing heights $(10,20,30$, or $40 \mathrm{~cm})$ distributed in randomized blocks with three replications (12 paddocks) and a no grazing control included among the treated blocks (2 paddocks). The size of the paddocks ranged from 0.8 (no grazing) to 3.6 ha (grazing) depending on the treatment applied, which is directly influenced by the stocking rate of the animals (Fig. 2b). During the stocking period, the pasture was exposed to continuous grazing with three tester steers per paddock. The grazing height was periodically monitored based on the measurement of 100 random points in each paddock using a graduated sward stick. Adjustments in the grazing heights were performed by adding animals as needed to maintain the pre-established grazing heights.
Fig. 2 a Geographic location of the integrated crop-livestock system in São Miguel das Missões, Rio Grande do Sul (RS), Brazil. b The experiment contained five treatments: four grazing heights $(10,20,30$, and $40 \mathrm{~cm}$ ) distributed in randomized blocks with three replications (12 paddocks) with an ungrazed (control) included among the treated blocks (2 paddocks). Paddocks had different sizes, based on the grazing treatment applied as following (left to right): 2.19 ha, 1.60 ha, 0.90 ha, 1.32 ha, 0.10 ha, 0.86 ha, 1.31 ha, 2.87 ha, 2.10 ha, 0.10 ha, 1.49 ha, 1.89 ha, 1.07 ha, and 3.53 ha. c Sampling design and placement of traps in the center of the grazed paddocks

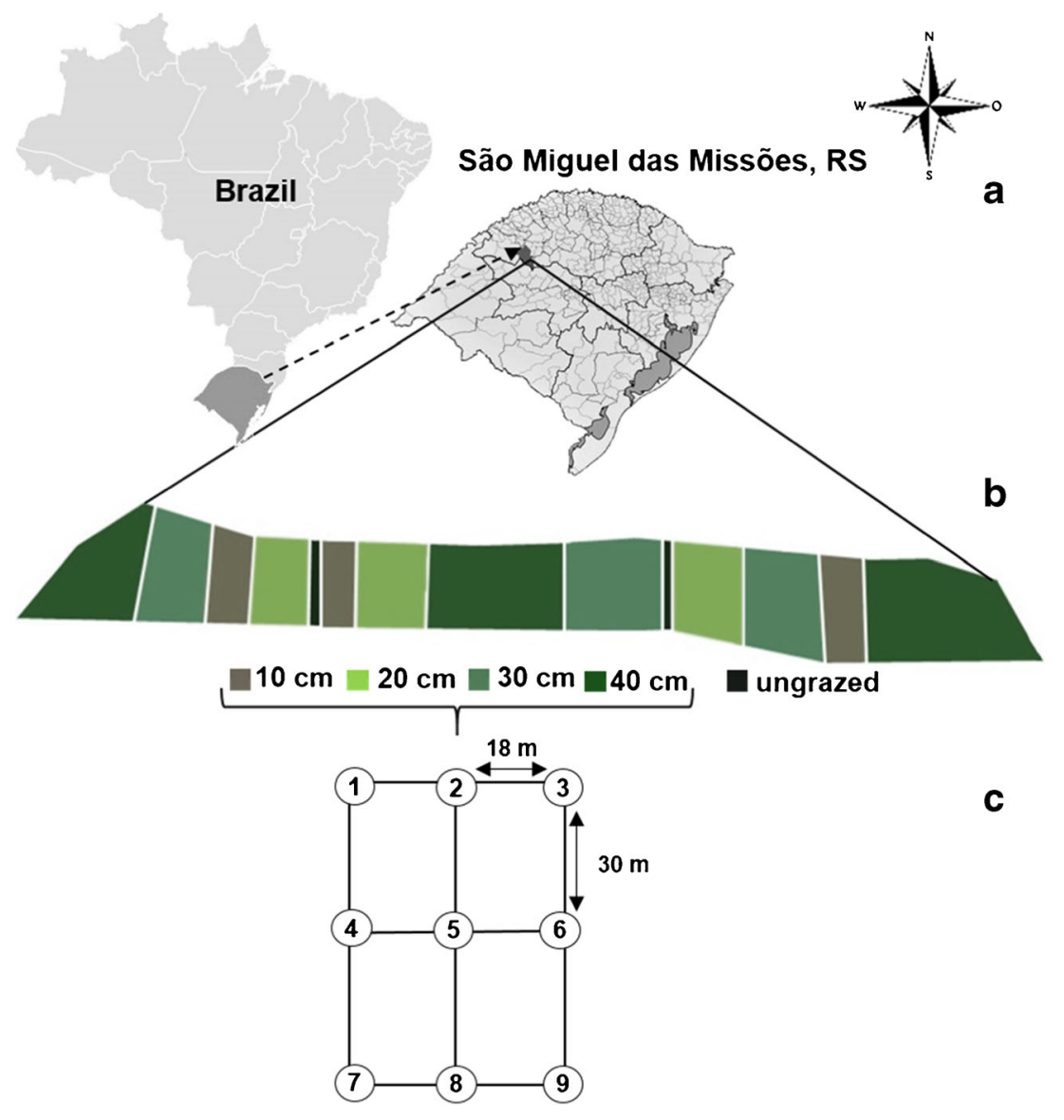


Sampling was conducted during four subsequent periods: two samplings during the "postgrazing" period at the end of the pasture cycle and immediately after the cattle were removed (from November 05-11, 2014 to November 1-7, 2015) and two samplings during the "postsoybean" period, immediately after the soybean harvest (from April 29May 06, 2015 to May 06-13, 2016). In total, we collected spiders from 432 traps (4 grazing treatments $\times 3$ blocks $\times 4$ sampling periods $\times 9$ traps). Data from the 9 traps were combined for the analyses (see below), representing 48 sampling units.

\subsection{Ground spider sampling}

A nine-point sampling design was established at the center of each grazing paddock during each sampling period. In each paddock, three $60 \mathrm{~m}$ transects spaced $18 \mathrm{~m}$ apart with three traps per transect were established (Fig. 2c). The spiders were sampled using pitfall traps, each of which consisted of a plastic container that was $10 \mathrm{~cm}$ in diameter and $20 \mathrm{~cm}$ deep and contained $500 \mathrm{~mL}$ of $80 \%$ ethanol. The traps were inserted into the ground so that the upper margin of the trap was aligned with the soil surface. In each collection event, the traps were placed in the same sampling locations according to geographic coordinates obtained with a real-time kinematic (RTK) GPS (1-cm accuracy) and remained in the field for 7 days. This study was conducted under the research permit number 4345-6 (SISBIO) issued by the Brazilian Ministry of the Environment.

In the laboratory, the collected spiders were preserved in an $80 \%$ ethanol solution, and all specimens were identified to the family level (adults were identified to the species level) using data from the literature. Species from the families Linyphiidae, Theridiidae, and Araneidae were identified at the Arachnida Diversity and Systematics Laboratory at Vale do Rio dos Sinos University (Universidade do Vale do Rio dos Sinos, UNISINOS), Brazil, and the other species were identified at the Arachnology Laboratory at Pontifical Catholic University of Rio Grande do Sul (Pontifícia Universidade Católica do Rio Grande do Sul, PUCRS). All specimens were deposited in the arachnology collection of the Natural Sciences Museum at PUCRS.

\subsection{Data analysis}

Because the environment and grazing height can affect reproduction (the number of juveniles produced) and survival (the number of juveniles that survive to become adults) of spiders (Mineo et al. 2010; Zmudzki and Laskowski 2012), we analyzed juvenile and adult (male and female) spiders separately.

The sampling sufficiency was assessed using a species accumulation curve based on the number of species found in each plot during the four collection events, totaling 48 sites.
Species richness was estimated using the Chao 1 estimator, which is adequate for comparing samples with different sizes that may contain rare species.

For the statistical analyses, we quantified the average abundance of all pitfalls in a sampling unit by dividing the total number of individuals sampled in a paddock by the number of pitfalls used $(n=9)$. Both family and species richness increased nonlinearly with sampling effort. Therefore, we rarefied the community data to calculate the average family and species richness per pitfall in each sampling unit.

The composition of the ground spider community was evaluated by the turnover of species and families associated with differences in the environment and grazing height. We calculated the Bray-Curtis dissimilarity between all pairs of sampling units $((48 \times 47) / 2=1128$ unique pairs $)$ separately for species and families. The association of the pairwise dissimilarities representing species and family composition for environment and grazing height was tested using a multivariate analysis of variance (adonis test). The composition analyses were conducted using the vegan $\mathrm{R}$ package (Oksanen et al. 2019).

The effects of environment (soybean vs. pasture) and grazing height on the abundance of juveniles, adult male and female spiders, total spider abundance, and on species and family richness were tested using linear mixed effects models (LMEs) fit by a maximum likelihood estimate. We used the ImerTest R package (Kuznetsova et al. 2017) for the model estimation, taking into account the sampling period (year) and block (spatial repetitions). The period and block were included as random effects on the intercept, and environment (postgrazing and postsoybean) and grazing height were included as fixed effects. The LME models were modeled with a Gaussian distribution because average abundance and rarefied richness are nonintegers. The coefficient of determination $\left(R^{2}\right)$ was partitioned into the variance explained by the fixed factors (marginal $R^{2}, R^{2} \mathrm{~m}$ ) and the variance explained by the entire model, including both fixed and random effects (conditional $R^{2}, R^{2} \mathrm{c}$ ). The coefficient of determination was calculated based on the likelihood-ratio test, using the r.squaredLR function of the MuMIn R package (Bartón 2019). All analyses were conducted using the $\mathrm{R}$ software version 3.6.0 ( $\mathrm{R}$ Core Team 2018).

\section{Results and discussion}

\subsection{Composition of the ground spider community associated with the integrated crop-livestock system}

The results presented here consistently support the hypothesis that in the integrated crop-livestock system, the composition of the spider community in the pasture differs from the composition documented after the soybean harvest. There were 
significant changes in the composition of species and families colonizing the soils of the two cultivation areas. The abundance of individuals was seven times higher, and the species richness was 33\% higher in pastures than in soybean.

Over the four samplings, a total of 2589 spiders were collected, of which, 1240 were juveniles and 1349 were adults (839 males and 510 females). The highest spider abundances were found in the postgrazing sampling events with 963 spiders in 2014 (51.8\% juveniles, $31.4 \%$ adult males, and $16.8 \%$ adult females) and 1306 in 2015 (43.9\% juveniles, 36.7\% adult males, and $19.4 \%$ adult females). In the postsoybean harvest sampling events, only 133 spiders were collected in 2015 (46.6\% juveniles, $23.3 \%$ adult males, and $30.1 \%$ adult females), and 187 spiders were collected in 2016 (56.7\% juveniles, $14.4 \%$ adult males, and $28.9 \%$ adult females).

The spiders were classified into 23 families and 43 species (Fig. 3). The Linyphiidae were the predominant family, representing $63.5 \%$ of the total spider abundance in the integrated crop-livestock system followed by the Lycosidae (13.1\%) and the Theridiidae (9.0\%). The Linyphiidae were most abundant in the postgrazing samples $(61.9 \%$ of the individuals in 2015 and $77.4 \%$ of the individuals in 2016) followed by the Lycosidae, Theridiidae, and Tetragnathidae. In the postsoybean harvest samples, the Theridiidae (34.6\%) and Lycosidae (24.8\%) predominated in 2015, and the Amphinectidae (34.7\%) and Theridiidae (24.6\%) predominated in 2016. The family composition differed between the postsoybean and postgrazing periods (adonis $p=0.001$; $R^{2}=0.48$ ). Analysis of the distribution patterns showed a strong association of Tetragnathidae with pastures and Gnaphosidae with postsoybean fields. The Linyphiidae, Lycosidae, Theridiidae, and Amphinectidae were persistent in the soybean-pasture succession system, being collected in both environments (Fig. 3a). These results partly corroborate inventories of spiders in Brazilian pastures from the Pampas biome, in which Lycosidae, Hahniidae, Linyphiidae, and Theridiidae were the most abundant families found in grazed areas, whereas Tetragnathidae was exclusively found in ungrazed areas (Silva and Ott 2017).

A total of 33 species were found in the postgrazing samplings, whereas 22 spider species were collected in the postsoybean harvest samplings (Fig. 3b). The species
Family abundance

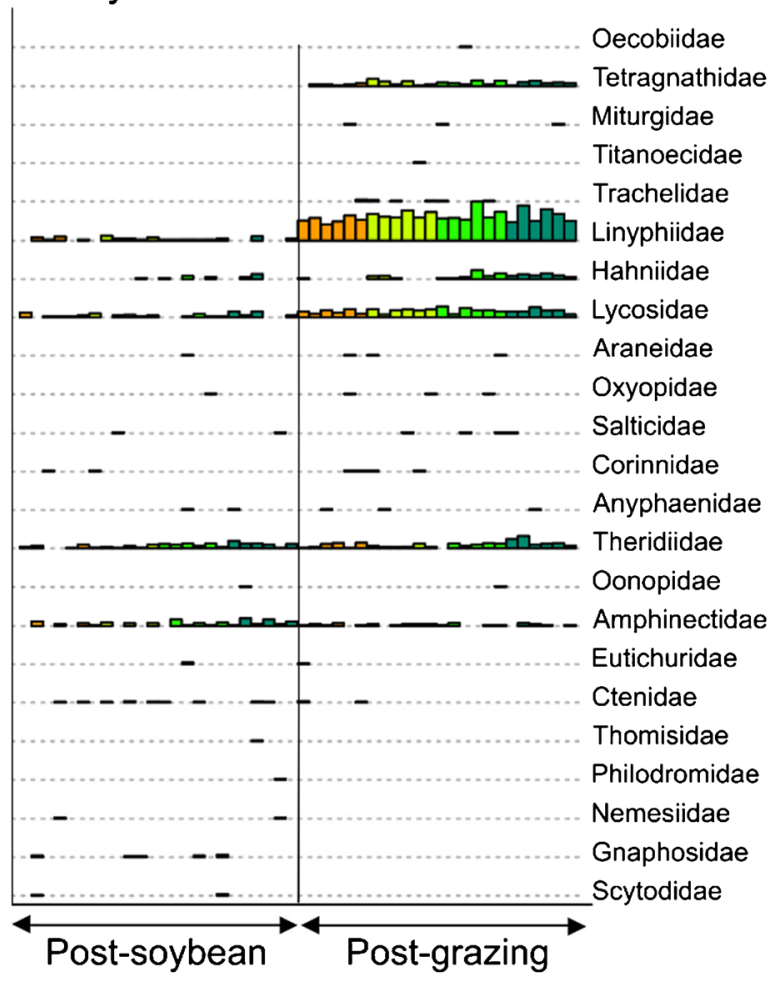

Species abundance

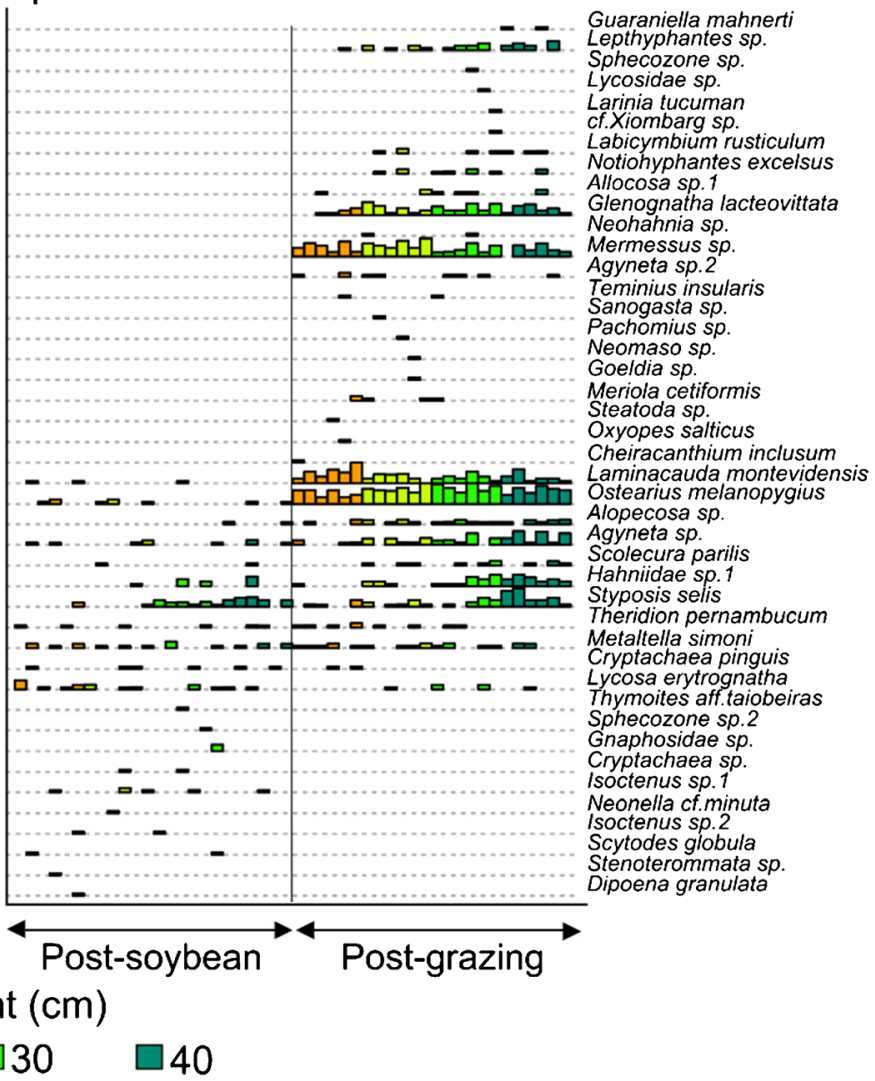

species (b). Although most spider families were observed in all treatments, some families (e.g., Linyphiidae) were much more abundant in the pasture (a). Several species were only observed in the pasture, and other species were exclusive to the soybean, (b) resulting in a strong change in species composition associated with the environment

b
Fig. 3 Abundance of ground spider families (a) and species (b) collected in an integrated crop-livestock system after soybean harvest (postsoybean) and after cattle grazing (postgrazing) in paddocks with grazing heights of 10,20,30, and $40 \mathrm{~cm}$. Each column in the graphs represents a sampling unit, and each row represents a family (a) or 
accumulation curve did not reach an asymptote (data not shown), indicating that part of the diversity of the ground spider community was not inventoried. Based on the Chao 1 richness estimator, a total of 66 species were predicted, so $65.2 \%$ of the estimated total species were sampled. The low richness of spider species sampled may reflect the limitation of the method and traps used, which focus on soil-associated spiders and capture the most active spiders during the sampling period. Although we captured spiders with web behavior and used high intensity sampling, the low spider richness may also be related to the different vegetation strata and microhabitats in the pasture compared with the homogeneous environment in the postsoybean paddocks that may restrict the occurrence of many species (Höfer and Brescovit 2001). Species composition differed between the soybean and pasture environments (adonis $p=0.001 ; R^{2}=0.31$ ). The species Styposis selis, Lycosa erytrognatha, Metaltella simoni, and Hahniidae sp.1 were most frequent in the postsoybean environment, and Ostearius melanopygius, Mermessus sp., Laminacauda montevidensis, and Glenognatha lacteovittata were associated with the postgrazing environment.

Changes in the composition of the spider community can be explained by the farming practices conducted in the integrated crop-livestock system. This agricultural system consists of a long and continuous soybean and pasture rotation (14 years) with environments of considerable homogeneity. In the postsoybean samplings, there were only crop residues and ryegrass seedlings in the initial stage of establishing, that may contributed to the low spider richness and abundance. Conversely, the postgrazing environment consisted of plants that ranged in biomass from 1.35 to $4.45 \mathrm{Mg} \mathrm{ha}^{-1}$ of shoot dry matter, with increasing biomass associated with the reduction in grazing intensity. Furthermore, during a soybean cycle, there are at least eight pesticide applications, which represent a considerable quantity of chemicals that are harmful to inver-

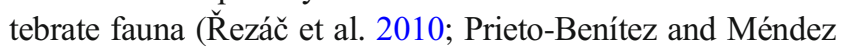
2011). Soybean harvesting also affects the spider community due to machinery traffic and particularly due to changes in vegetation structure (Kerzicnik et al. 2013). There is no pesticide application or machinery traffic during the grazing cycle, but intensified grazing can affect the arthropod communities through environmental disturbance, changes in plant diversity and vegetation structure, and a reduction in total resource abundance. However, the pasture environment in our study provided abundant plant resources when compared with the soybean environment. The density and height of the plants were higher and the continuous presence of cattle on the pasture contributed to the deposition of dung on the soil surface. Under such conditions, various soil meso- and macrofauna such as earthworms, beetles, diplopods, and mites are found and consequently attract predators such as spiders (personal observations made at the experimental site). It is possible that the presence of cattle dung led to an increase in the quantity and diversity of prey, which led to changes in the composition of the spider community.

In addition, the continuous trampling by the animals creates an uneven surface within the pasture, producing plant layers of varying heights that increase environmental complexity and favor the ground spider community (Schmidt et al. 2005; Dennis et al. 2015). Variation in vegetation architecture between the environments may explain differences in spider community composition (Gómez et al. 2016). In the pasture environment, the plant density was approximately $3,000,000$ plants per ha (compared with $\sim 300,000$ in the soybean environment), and the linear leaves, the high number of tillers, and the architecture of the grasses may facilitate the construction of webs at the soil-plant interface and provide shelter to spiders (Podgaiski et al. 2013; Gómez et al. 2016). These environmental differences between the pasture and soybean environments caused certain species and families to occur in only one of the cropping areas or to show large population variation between the areas. Consequently, the strategies employed by the spiders to obtain resources also differed between the pasture and soybean environments. Glenognatha lacteovitatta, for example, occurred only within the pasture cycle at a grazing height above $20 \mathrm{~cm}$. At these grazing intensities, this species found a more stable leaf arrangement to build its orb web (Podgaiski et al. 2013). After the soybean harvest, space web weavers predominated as indicated by the abundance of Theridiidae, as also reported by Liljesthröm et al. (2002). This family has a sedentary habit and can associate with lower vegetation strata by building their webs close to the ground in soybean crop litter. However, we found the theridid Styposis selis in both postsoybean and postgrazing environments, mainly associated with lower grazing intensity $(40 \mathrm{~cm})$.

Some species were recurrent throughout the soybeanpasture succession system (Fig. 3b), suggesting that these species can persist in environments with a high degree of human interference. The Linyphiidae spiders, particularly those in the subfamily Erigoninae, which exhibited higher abundance and species richness in the integrated crop-livestock system, are often associated with disturbed environments (Clark et al. 2004). This family is abundant in inventories associated with pasture (Clark et al. 2004), corn cropping areas (Royauté and Buddle 2012), coffee plantations (Marín et al. 2016), and Pinus plantations (Podgaiski and Rodrigues 2017). The most abundant species observed in this integrated crop-livestock system was Ostearius melanopigius, an agrobiont and cosmopolitan species typical of disturbed habitats (Szinetár and Samu 2012).

We documented a significant effect of environment on the composition of spiders in the integrated crop-livestock system; however, considerable variation remained unexplained both for family (52\%) and species richness (69\%). Seasonal variation in abiotic conditions (Aisen et al. 2017) and 
Table 1 Summary of the generalized linear mixed effects models (LMEs) testing for the effect of grazing height and environment (pasture vs. soybean) on the abundance and species richness of ground spiders. $R^{2} \mathrm{~m}$ : Variance of response variables explained by grazing and the environment (fixed effects; marginal). $\mathrm{R}^{2} \mathrm{c}$ : Total variance of response variables explained by grazing and the environment (fixed effects) and by year and blocks (random effects). Model: $\mathrm{y} \sim$ grazing height + environment (postgrazing, postsoybean) $+(1 \mid$ sampling period (year) + (1|block)

\begin{tabular}{|c|c|c|c|c|c|c|c|c|}
\hline \multirow[t]{2}{*}{ Response variable } & \multicolumn{3}{|c|}{ Fixed effects } & \multicolumn{2}{|c|}{ Random effects } & \multirow[t]{2}{*}{ Df } & \multicolumn{2}{|l|}{$R^{2}$} \\
\hline & Intercept & Grazing height & Environment & Year & Blocks & & $R^{2} \mathrm{~m}$ & $R^{2} \mathrm{c}$ \\
\hline Abundance & $8.335^{* *}$ & $0.105^{* * *}$ & $-9.431 *$ & 1.691 & 0.402 & 48 & 0.76 & 0.86 \\
\hline Juvenile & $3.993 * * *$ & $0.047 * *$ & $-4.372 *$ & 0.336 & 0.247 & 48 & 0.78 & 0.81 \\
\hline Male & $2.839 *$ & $0.037 * *$ & $-3.494^{\mathrm{ns}}$ & 0.851 & $<0.001$ & 48 & 0.67 & 0.81 \\
\hline Female & $1.502 *$ & $0.020 * *$ & $-1.565^{\mathrm{ns}}$ & 0.457 & 0.0978 & 48 & 0.58 & 0.76 \\
\hline Family richness & $1.040 * * *$ & $0.010^{* * *}$ & $-0.964 * *$ & 0.005 & $<0.001$ & 48 & 0.85 & 0.86 \\
\hline Species richness & $0.658 * * *$ & $0.006^{* *}$ & $-0.652 *$ & 0.077 & $<0.001$ & 48 & 0.80 & 0.84 \\
\hline
\end{tabular}

$p$ value $\left(^{*}<0.05,{ }^{* *}<0.01\right.$, and $\left.{ }^{* * *}<0.001\right)$

environmental characteristics such as vegetation structure and prey availability (Dennis et al. 2015; Michalko et al. 2019) may influence spider abundance and richness. During the sampling periods, we recorded an average of $24.9{ }^{\circ} \mathrm{C}$, $14.8^{\circ} \mathrm{C}$, and $19.8^{\circ} \mathrm{C}$ for maximum, minimum, and average temperature, respectively, and $15.6 \mathrm{~mm}$ average rainfall during the postgrazing periods; during the postsoybean periods, the averages for the weather variables from the two samplings were $20.0^{\circ} \mathrm{C}, 11.3^{\circ} \mathrm{C}$, and $15.7^{\circ} \mathrm{C}$ for maximum, minimum, and average temperature, respectively, and $7.2 \mathrm{~mm}$ average rainfall. These variables exhibited little variation due to the mild weather conditions during the samplings, which were performed in the spring (postgrazing) and autumn (postsoybean) seasons. Despite this lack of variation in temperature and rainfall, other random variables not measured may have affected the composition of the ground spider community.

\subsection{Effect of grazing height on the composition of the ground spider community}

The results of the generalized linear mixed effects models supported our second hypothesis that the ground spider community is strongly influenced by grazing intensity (Table 1). There was a positive and significant relationship between ground spider abundance, species richness and family richness, and grazing height (reflecting decreasing grazing intensity). The models explained $86 \%, 81 \%, 81 \%$, and $76 \%\left(R^{2} \mathrm{c}\right)$ of the variation in the abundance of juveniles, males, females, and all individuals, respectively (Fig. 4a, b, c, and d). Environment did not have a significant effect on male and female spider abundance. Family (Fig. 4e) and species richness (Fig. 4f) showed a positive and highly significant relationship with grazing height, with $86 \%$ and $84 \%\left(R^{2} \mathrm{c}\right)$ of the variation, respectively, explained by the model.
In the postgrazing sampling, grazing created a vegetation structure with an environmental gradient of welldefined variation in pasture height. After the soybean harvest, the environment was more homogeneous, but the plant residues added to the soil by the winter pasture also positively influenced the variation in spider abundance and richness as a function of pasture height. This pattern has also been observed in other studies, demonstrating that increased grazing intensity reduced spider abundance (Dennis et al. 2015) and species richness (Horváth et al. 2009). Higher grazing heights provide more complex vegetation structures, which foster greater abundance and species and family richness (Schmidt et al. 2005). This environmental complexity favors the presence of spiders that benefit from the formation of microhabitats (Bell et al. 2001) and from higher prey availability (Dennis et al. 2015), which create better conditions for habitat exploitation and an increased number of spiders (Marín et al. 2016). According to Bucher et al. (2016), cattle grazing at low stocking rates promotes spider diversity through vegetation heterogeneity, and this type of pasture management can contribute to biodiversity conservation and improve prey availability for other predators.

Our results showed that there was a greater abundance of males than females in both environments, indicating greater male activity. This activity may be related to the wandering behavior of males in search of more sessile female spiders, increasing the likelihood of males being caught in the interception traps (Mineo et al. 2010; Bizuet-Flores et al. 2015). The higher abundance of juveniles observed after both the grazing and soybean cycles suggests a constant recolonization of the environment. Spiders can colonize environments through active movement on the ground or long-distance migration through passive aerial dispersion (ballooning) (Bell et al. 2001). These means of dispersion can facilitate the rapid recovery of the spider community after a major disturbance 
Fig. 4 Effect of grazing height $(10,20,30$, and $40 \mathrm{~cm})$ on the abundance (number) of juveniles (a), males (b), females (c), total ground spiders (d), and family richness (e) and species richness (f). Each point corresponds to a sample unit (paddock) management targets for continuously stocked mixed oat $x$ annual ryegrass pasture in a no-till integrated crop-livestock system and represents the average abundance (male, female, juvenile, or total abundance) or the rarefied richness (family or species). Different colors indicate the postgrazing environment (green) and the postsoybean environment (orange).

Predictions were based on linear mixed effects models (LMEs) that include random effects (sampling period, 2 years postsoybean and 2 years in postgrazing) and blocks (spatial replications). Abundance and richness were higher in postgrazing (pasture) compared with postsoybean environments, and grazing intensity (lower pasture height) negatively affected the abundance and richness of ground spiders, mainly in the postgrazing environment
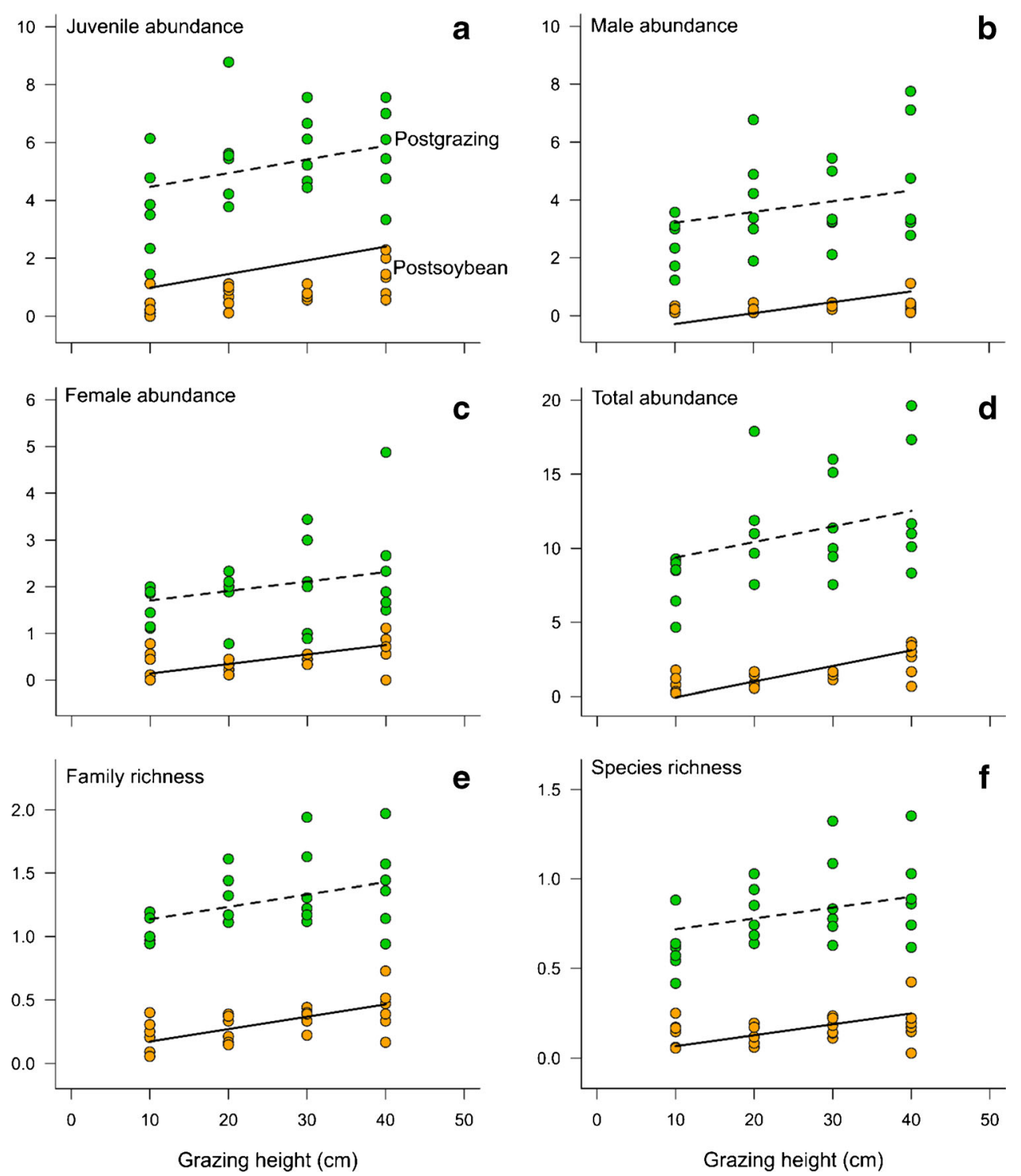

(Szinetár and Samu 2012). The process of colonization can be constant and mediated by dispersers that remain at the site due to food availability. One strategy to enhance spider recolonization is to maintain the landscape surrounding agricultural areas as a refuge. At the experimental site where the samplings were conducted, there is an area of natural vegetation adjacent to all the paddocks, which the spiders may have used as a refuge, thus playing an important role in agroecosystem services.

\section{Conclusions}

This study contributes information supporting a more comprehensive use of the agroecosystem with the aim of reconciling agricultural production and sustainability. The significant reduction in the abundance and richness of spiders in collections following the soybean cycles compared with those following the pasture cycles suggests that the spider fauna is impacted by soybean cultivation. The introduction of a pasture cycle into a purely agricultural production system leads to several modifications that are beneficial to the fauna such as the increased input of plant and animal residues into the soil and reduced pesticide application and machinery traffic, that allow the spider community to be more abundant and more diverse. Increasing the abundance and diversity of ground spiders results in greater environmental balance, the promotion of ecosystem services (pest population control), and a reduced need to use pesticides, which contribute to increased agricultural sustainability. However, pasture management should prioritize reducing the stocking density to maintain a more diverse soil fauna community because grazing intensification is associated with a reduction in the abundance and richness of spider families and species. 
Acknowledgments The authors thank the Grupo de Pesquisa em Sistemas Integrados de Produção Agropecuária of the Universidade Federal do Rio Grande do Sul management targets for continuously stocked mixed oat $\times$ annual ryegrass pasture in a no-till integrated croplivestock system for the commitment and persistence in conducting a long-term experiment that allowed the accomplishment of this work; the research group of the Laboratorio de Biologia do Solo of the Universidade Federal de Santa Maria for their assistance in the field and the laboratory; and Leocadia Falkemberg Indrusiak, Arno Antônio Lise, and Miguel Machado for the assistance in spider identification.

Funding information This study was funded by Conselho Nacional de Desenvolvimento Científico e Tecnológico (CNPq); Coordenação de Aperfeiçoamento de Pessoal de Nível Superior (CAPES), Brasil, Finance Code 001; Fundação de Amparo à Pesquisa do Estado do Rio Grande do Sul (FAPERGS); and Fundação AGRISUS, Agricultura Sustentável.

\section{Compliance with ethical standards}

Conflict of interest The authors declare that they have no conflict of interest.

Ethical approval This study was conducted under the research permit number 4345-6 (SISBIO) issued by the Brazilian Ministry of the Environment.

\section{References}

Aisen S, Werenkraut V, Márquez MEG, Ramírez MJ, Ruggiero A (2017) Environmental heterogeneity, not distance, structures montane epigaeic spider assemblages in north-western Patagonia (Argentina). J Insect Conserv 21:951-962. https://doi.org/10.1007/ s10841-017-0034-8

Bartón K (2019) MuMIn: Multi-Model Inference. R package version 1.43.6. https://CRAN.R-project.org/package=MuMIn

Bell J, Wheater C, Cullen W (2001) The implications of grassland and heathland management for the conservation of spider communities: a review. J Zool 255:377-387. https://doi.org/10.1017/ s0952836901001479

Bender SF, Wagg C, van der Heijden MGA (2016) An underground revolution: biodiversity and soil ecological engineering for agricultural sustainability. Trends Ecol Evol 31:440-452. https://doi.org/ 10.1016/j.tree.2016.02.016

Bizuet-flores MY, Jiménez-jiménez ML, Zavala-hurtado A, Corcuera P (2015) Diversity patterns of ground dwelling spiders (Arachnida: Araneae) in five prevailing plant communities of the Cuatro Ciénegas Basin, Coahuila, Mexico. Rev Mex Biodivers 86:153163. https://doi.org/10.7550/rmb.45444Z

Bucher R, Andres C, Wedel MF, Entling MH, Nickel H (2016) Biodiversity in low-intensity pastures, straw meadows, and fallows of a fen area - a multitrophic comparison. Agric Ecosyst Environ 219:190-196. https://doi.org/10.1016/j.agee.2015.12.019

Clark RJ, Gerard PJ, Mellsop JM (2004) Spider biodiversity and density following cultivation in pastures in the Waikato, New Zealand. N Z J Agric Res 47:247-259. https://doi.org/10.1080/00288233.2004. 9513592

Dennis P, Skartveit J, Kunaver A, McCracken DI (2015) The response of spider (Araneae) assemblages to structural heterogeneity and prey abundance in sub-montane vegetation modified by conservation grazing. Glob Ecol Conserv 3:715-728. https://doi.org/10.1016/j. gecco.2015.03.007
Eldridge DJ, Delgado-Baquerizo M, Travers SK, Val J, Oliver I (2017) Do grazing intensity and herbivore type affect soil health? Insights from a semi-arid productivity gradient. J Appl Ecol 54:976-985. https://doi.org/10.1111/1365-2664.12834

Gallé R, Vesztergom N, Somogyi T (2011) Environmental conditions affecting spiders in grasslands at the lower reach of the River Tisza in Hungary. Entomol Fennica 22:29-38 https://journal.fi/ entomolfennica/article/view/4241/3955

Gómez JE, Lohmiller J, Joern A (2016) Importance of vegetation structure to the assembly of an aerial web-building spider community in North American open grassland. J Arachnol 44:28-35 http://www. bioone.org/doi/full/10.1636/P14-58.1

Haddad GQ, Cividanes FJ, Martins ICF (2011) Species diversity of myrmecofauna and araneofauna associated with agroecosystem and forest fragments and their interaction with Carabidae and Staphylinidae (Coleoptera). Fla Entomol 94:500-509. https://doi. org/10.1653/024.094.0314

Herrero M, Thornton PK, Notenbaert AM, Wood S, Msangi S, Freeman HA, Bossio D, Dixon J, Peters M, van de Steeg J, Lynam J, Rao PP, Macmillan S, Gerard B, McDermott J, Sere C, Rosegrant M (2010) Smart investments in sustainable food production: revisiting mixed crop livestock systems. Science 80:822-825. https://doi.org/10. 1126/science. 1183725

Höfer H, Brescovit AD (2001) Species and guild structure of a Neotropical spider assemblage (Araneae) from Reserva Ducke, Amazonas, Brazil. Andrias 15:99-119 https:/www.zobodat.at/pdf/ Andrias_15_0099-0119.pdf

Horváth R, Magura T, Szinetár C, Tóthmérész B (2009) Spiders are not less diverse in small and isolated grasslands, but less diverse in overgrazed grasslands: a field study (East Hungary, Nyírség). Agric Ecosyst Environ 130:16-22. https://doi.org/10.1016/j.agee. 2008.11.011

Kerzicnik LM, Peairs FB, Cushing PE, Draney ML, Merrill SC (2013) Spider fauna of semiarid eastern Colorado agroecosystems: diversity, abundance, and effects of crop intensification. Environ Entomol 42:131-142. https://doi.org/10.1603/EN12186

Kunrath TR, Cadenazzi M, Martins D, Anghinoni I, de Moraes A, Santiago R, César P, Carvalho DF (2014) Management targets for continuously stocked mixed oat $\times$ annual ryegrass pasture in a no-till integrated crop-livestock system. Eur J Agron 57:71-76. https://doi. org/10.1016/j.eja.2013.09.013

Kunrath TR, de F Carvalho PC, Cadenazzi M, Bredemeier C, Anghinoni I (2015) Grazing management in an integrated crop-livestock system: soybean development and grain yield. Rev Ciênc Agron 46: 645-653. https://doi.org/10.5935/1806-6690.20150049

Kuznetsova A, Brockhoff PB, Christensen RHB (2017) lmerTest package: tests in linear mixed effects models. J Stat Softw 82:1-26. https://doi.org/10.18637/jss.v082.i13

Liljesthröm G, Minervino E, Castro D, Gonzalez A (2002) La comunidad de arañas del cultivo de soja em la província de Buenos Aires, Argentina. Neotrop Entomol 31:197-210. https://doi.org/10.1590/ S1519-566X2002000200005

Marín L, Philpott SM, De la Mora A, Ibarra Núñez G, Tryban S, Perfecto I (2016) Response of ground spiders to local and landscape factors in a Mexican coffee landscape. Agric Ecosyst Environ 222:80-92. https://doi.org/10.1016/j.agee.2016.01.051

Michalko R, Pekár S, Entling MH (2019) An updated perspective on spiders as generalist predators in biological control. Oecologia 189:21-36. https://doi.org/10.1007/s00442-018-4313-1

Mineo MF, Del-claro K, Brescovit AD (2010) Seasonal variation of ground spiders in a Brazilian Savanna. Zoologia 27:353-362. https://doi.org/10.1590/S1984-46702010000300006

Moraes A, Carvalho PCF, Anghinoni I, Lustosa SBC, Csta SEVGA, Kunrath TR (2014) Integrated crop-livestock systems in the Brazilian subtropics. Eur J Agron 57:4-9. https://doi.org/10.1016/j. eja.2013.10.004 
Oksanen J, Blanchet FG, Friendly M, Kindt R, Legendre P, McGlinn D, Minchin PR, O'Hara RB, Simpson GL, Solymos P, Stevens HMH, Szoecs E, Wagner H (2019) Vegan: community ecology package. R package version 2.5-5. https://CRAN.R-project.org/package=vegan

Pekár S, Michalko R, Líznarová E, Loverre P, Černecká L (2015) Biological control in winter: novel evidence for the importance of generalist predators. J Appl Ecol 52:270-279. https://doi.org/10. 1111/1365-2664.12363

Podgaiski LR, Rodrigues GG (2017) Spider community responds to litter complexity: insights from a small-scale experiment in an exotic pine stand. jafreiberg@mail.ufsm.br, https://doi.org/10.1590/1678$4766 \mathrm{e} 2017007$

Podgaiski LR, Joner F, Lavorel S, Moretti M, Ibanez S, Mendonça MS Jr (2013) Spider trait assembly patterns and resilience under fireinduced vegetation change in South Brazilian grasslands. PLoS One 8:e60207. https://doi.org/10.1371/journal.pone.0060207

Prieto-Benítez S, Méndez M (2011) Effects of land management on the abundance and richness of spiders (Araneae): a meta-analysis. Biol Conserv 144:683-691. https://doi.org/10.1016/j.biocon.2010.11. 024

R Core Team (2018) R: a language and environment for statistical computing. R Foundation for Statistical Computing, Vienna https:// www.R-project.org/

Řezáč M, Pekár S, Stará J (2010) The negative effect of some selective insecticides on the functional response of a potential biological control agent, the spider Philodromus cespitum. BioControl 55:5035010. https://doi.org/10.1007/s10526-010-9272-3

Rockström J, Williams J, Daily G, Noble A, Matthews N, Gordon L, Wetterstrand H, DeClerck F, Shah M, Steduto P, de Fraiture C,
Hatibu N, Unver O, Bird J, Sibanda L, Smith J (2017) Sustainable intensification of agriculture for human prosperity and global sustainability. Ambio 46:4-17. https://doi.org/10.1007/s13280-0160793-6

Rodrigues ENL, Mendonça MS Jr, Fritz LL, Heinrichs EA, Fiuza L (2013) Effect of the insecticide Lambda-cyhalothrin on rice spider populations in southern Brazil. Zoologia 30:615-622. https://doi. org/10.1590/s1984-46702013005000010

Royauté R, Buddle CM (2012) Colonization dynamics of agroecosystem spider assemblages after snow-melt in Quebec (Canada). J Arachnol 40:48-58. https://doi.org/10.1636/P11-16.1

Schmidt MH, Roschewitz I, Thies C (2005) Differential effects of landscape and management on diversity and density of ground-dwelling farmland spiders. J Appl Ecol 42:281-287. https://doi.org/10.1111/j. 1365-2664.2005.01014.x

Silva GO, Ott R (2017) Short-term spider community monitoring after cattle removal in grazed grassland. Iheringia Sér Zool 107: e2017033. https://doi.org/10.1590/1678-4766e2017033

Szinetár C, Samu F (2012) Intensive grazing opens spider assemblage to invasion by disturbance-tolerant species. J Arachnol 40:59-70. https://doi.org/10.1636/P11-55.1

Zmudzki S, Laskowski R (2012) Biodiversity and structure of spider communities along a metal pollution gradient. Ecotoxicology 21: 1523-1532. https://doi.org/10.1007/s10646-012-0906-3

Publisher's note Springer Nature remains neutral with regard to jurisdictional claims in published maps and institutional affiliations. 